\title{
Australia and China's Rise: Ambivalent and Inevitable Balancing
}

\author{
Takashi TERADA
}

\begin{abstract}
China's dual function for Australia as a chief source of economic opportunity and security concern has complicated Australia's foreign and defence policies over the last decades. This paper aims to depict how Australia has dealt with China's dual significance, and identify Australia's struggles to maximise its own economic and security interests, tracing the need to strengthen cooperative economic relations with China while simultaneously endeavouring to maintain a robust alliance with the United States. The worst scenario for Australia would be for its largest trading partner and its significant ally to collide. Australia thus accentuates the significance of coordinated efforts to encourage China to take a constructive, not hegemonic, behaviour through, for instance, engaging it in multilateral forums.
\end{abstract}

\section{Keywords}

China's rise, Australia, Trilateral Strategic Dialogue (TSD)

\section{Introduction}

East Asia has emerged as an increasingly significant region in international politics and economics, and the global acknowledgement of the significance of East Asia has been mainly attributed to the rise of China. The rise of China means that a traditional political power that once lacked economic prowess is emerging as a potentially true superpower whose political influence is now backed by continuous high economic growth, impacting both political and economic spheres. This view was more fully developed after the global financial crisis, which represents both the eroding international influence of the United States and the growing international role of China with the world largest foreign reserves. A 
great number of nations are affected by this epochal phenomenon, and Australia is not an exception.

For instance, in the wake of the global financial crisis, Beijing implemented a quick and decisive injection of a four trillion-yuan package in November 2008 to boost domestic demand through ten measures, including the expansion of transportation networks and the development of health and education infrastructures. Australia soon became one of the largest beneficiaries from this package, as this created a substantial degree of demand for iron ore and coal. Consequently, the average price of iron ore in 2009 was doubled due to rising demand mainly in China, contributing to massive amounts of investment in mining industries in Australia. This China-led energy boom was instrumental in aiding Australia's quick recovery from the global financial crisis and 3.5 percent growth in 2009. Deputy Prime Minister Swan declared in September 2010: "We are located in the right part of the world at the right time for the first time in our history,"1 representing a view that Australia's 'tyranny of distance' sentiment was ending, thanks to China and other East Asian states.

On the other hand, China has been regarded as a threat in Australia; a public poll conducted by Australia's Lowy Institute in 2008 showed that $64 \%$ of Australian respondents disagreed that Australia's interest would not be harmed if China gained more power and influence. ${ }^{2}$ This concern was partly reflected in a defence white paper published the following year, which asserted, "A major power of China's stature can be expected to develop a globally significant military capability befitting its size. But the pace, scope and structure of China's military modernisation have the potential to give its neighbours cause for concern if not carefully explained, and if China does not reach out to others to build coincidence regarding its military plans." China's dual function for Australia as a chief source of economic opportunity and a security concern was summarised, by Prime Minister Julia Gillard at the beginning of the Asian Century white paper published in November 2011, as Australia's "largest export market and largest trading partner neither a democracy nor part of our alliance system, a nation whose economic transformation is in turn transforming the economic and strategic balance of our world." ${ }^{3}$ The transformed economic balance caused by China's rise has been a positive development Australia finds imperative to capitalise on, like many other

\footnotetext{
${ }^{1}$ Sydney Morning Herald, May 22, 2012.

2 Fergus Hanson, "2008 Lowy Poll: Australians Wary over China's Rise," Lowy Institute for International Policy, September 30, 2008, http://www.lowyinterpreter.org/ post/2008/09/30/2008-Lowy-Institute-Poll-China.aspx

3 Julia Gillard, Speech to the AsiaLink and Asia Society Lunch, Melbourne, Australia, September 28, 2011, http://www.pm.gov.au/press-office/speech-asialink-and-asia-society-lunchmelbourne
} 
nations, while the change in the strategic balance has been carefully managed to minimize security and defence concerns. This paper aims to depict how Australia has dealt with China's dual significance and identify Australia's struggles to maximise its own economic and security interests: the need to strengthen cooperative economic relations with China while simultaneously endeavouring to maintain a robust alliance with the United States. The worst scenario for Australia would be for its largest trading partner and significant ally to collide. As a third option, Australia finds it imperative to make an effort to encourage China to take a constructive, not hegemonic, behaviour by engaging it in multilateral forums.

\section{China's Economic Rise}

Australia's firm interest in maintaining a strong economic relationship with China has been evident in most of all Australian leaders' statements given the fact that China has been the world's largest importer of wool and iron ore, Australia's two major exporting products. This interest became more apparent when China overtook Japan as Australia's largest trading partner in 2007. Australia's possibility of concluding an FTA with China, which was seen as an important shift in Australia's strategic thinking, was reflected in the Australian media's increasing coverage of China rather than Japan. ${ }^{4}$ Prime Minister Julia Gillard visited Japan and China in April 2011, both of which were well covered by Australia's media; but the foci of the two visits were different. Gillard was highlighted by the Japanese media as the first foreign leader to visit the areas substantially demolished by the 3.11 Earthquake and Tsunami, illustrating Australia's serious consideration about Japan as a political and strategic partner. ${ }^{5}$ While the United States, an ally of Japan, provided enormous material, personnel, and moral support with Japan through the Tomodachi Operation, a visit by its political leader was not realised until Vice President Joe Biden visited Fukushima Prefecture in August 2011. This indicates the political significance of Gillard's visit to the town of Minami-sanriku in Miyagi Prefecture. She subsequently visited China with 150 Australian business leaders, the purpose of which was purely businessdriven; Australia signed an agreement with China on an annual supply of 4.3 million tons of liquid natural gas (LNG) over the next 20 years, one of Australia's largest international energy deals. In fact, Gillard was criticised at home for taking no action against China's poor human rights record, as was symbolised by the continued detention of 2010 Nobel laureate, Liu Xiaobo.

\footnotetext{
${ }^{4}$ David Walton, "Australia and Japan," in Trading on Alliance Security: Australia in World Affairs, 2001-2005, ed. James Cotton and John Ravenhill (Oxford University Press, 2007).

5 Nihon Keizai Shimbun, April 23, 2011.
} 
The fact that Australia has continued to rely on China for economic growth, as seen in its exports to China accounting for nearly $25 \%$ of its total exports in 2010, represents Australia's economic vulnerability with China. Therefore, it is imperative for Australia to intensify efforts to broaden and diversify its trade and investment routes and options. India, Australia's third-largest export market, has emerged as a potential trading partner to help Australia diversify its trade direction. The usefulness of India in this context can be seen in a 2011-2012 budget paper that stressed the need for reform in Australia's coal and mining industries to maintain and hopefully boost the current growth rate; India is juxtaposed with China as follows:

The mining boom is an early manifestation for Australia of the shift in the world's economic geography from west to east. As China and India continue to develop, the growing cities now driving demand for Australia's mineral resources will be populated by an increasingly wealthy and upwardly mobile middle class, with incomes and tastes to match. Increasing consumer purchasing power and changing spending patterns will open up new, often unforeseen, opportunities for Australia - well beyond those flowing from the current mining boom. ${ }^{6}$

Australia's bilateral and regional trading arrangements, which include India, are considered ways to reduce its dependence on the Chinese market and illustrate Australia's acknowledgement of the risks of its heavy dependence on the Chinese market for economic growth. This point was mentioned in a new trade strategy report, launched in April 2011, which pointed to the primacy of the multilateral trading system, including the WTO, and viewed bilateral and regional FTAs as supplementary to support the multilateral trading system. Nonetheless, given that the WTO's Doha Development Round negotiations have been bogged down over the last years, the pursuit of bilateral and regional trading arrangements is a more realistic path toward reducing trade barriers and diversifying dependence on China's market. As this trade policy report also suggests, Gillard's highest priority in terms of regional trading arrangements is placed on the conclusion of the Trans-Pacific Partnership Agreement (TPP), which excludes China as a member. This statement was, however, made possible only because Australia still has hope to eventually secure China's gigantic market preferentially through the conclusion of a bilateral FTA, which Australia has been negotiating since 2006, as well as a regional trading arrangement such as the Regional Comprehensive Economic Partnership (RECP) agreement, which consists of ASEAN+6 member countries.

\footnotetext{
${ }^{6}$ Australian Government, Budget Paper No. 1, May 10, 2011, http://www.budget.gov.au/201112/content/bp1/html/bp1_bst4-03.htm
} 
One significant political implication of growing mutual economic interdependence between Australia and China is Australia's tendency not to raise issues or contest China's political position on issues China hesitates to acknowledge, such as human rights. In other words, while China's economic development and massive capacity to absorb natural resources continues to be seen as the most significant factor helping Australia's economic growth, their mutual interdependence makes Australia's capacity to maintain its voice on China's political and military problems vulnerable, as seen in the case of the Trilateral Strategic Dialogue (TSD) and a quadrilateral approach.

\section{Australia's Vulnerability: Trilateral Strategic Dialogue}

According to White, an approach to trilateral cooperation among Australia, Japan, and the United States was generated accidentally at the 2001 AUSMIN in Sydney, the first round held during the Bush administration. However, this accident was surely associated with Australia's vulnerability against China. At a press conference, when asked about the "Asian NATO" issue in his meeting with Downer, Powell replied by mentioning something related to a forum among U.S. allies in Asia. Downer, who hoped to avoid antagonizing China with such a politically sensitive idea, tried to redirect attention toward the idea of a trilateral dialogue, which Australia had previously been interested in and which Downer had not intended to say anything about. In White's words, "the idea would not have been aired at all had Powell not responded as he did to the question." ${ }^{, 7}$ Nevertheless, Downer's adlib catalysed the process toward realization, and several meetings at the senior official level, involving Richard Armitage, Ashton Calvert, and Yukio Takeuchi, were held from 2002 to 2004.

In early 2005, the elevation of the trilateral senior official meeting to the ministerial level was announced by Condoleezza Rice, the new U.S. Secretary of State. This elevation was mainly attributed to growing concerns of the United States and Japan about Australia's divergent interests regarding the rise of China. Australia's actions in relation to China have not followed the preferred course of Japan and the United States. White cited three evidences in which the United States found Australia's distinctive interests in and approaches to China: 1) the equal treatment to Presidents Bush and $\mathrm{Hu}$, who visited Australia on consecutive days in Octo-

\footnotetext{
${ }^{7}$ Hugh White, "Trilateralism and Australia: Australia and the Trilateral Security Dialogue with America and Japan," in Asia Pacific Security: U.S., Australia and Japan and the New Security Triangle, ed. William T. Tow et al. (Routledge, 2007), 107-108.
} 
ber 2003; 2) Downer's statement on Australia's lack of obligation to support the United States in any conflict against China over Taiwan in August 2004; and 3) Australia's rejection to join the United States and Japan in pressing the European Union not to eliminate restrictions on arms sales to China in February 2005. Australia's softer stance on China was partly arising from its firm interest in maintaining a strong economic relationship with China, the world's largest importer of wool and iron ore. This interest was to become even stronger as China overtook Japan as Australia's largest trading partner in 2007.

The possibility of concluding an FTA with China was seen as an important shift in Australia's strategic thinking, which was reflected in the Australian media's increasing coverage of China rather than Japan. ${ }^{9}$ The Australian senior diplomat in charge of Northeast Asian affairs acknowledged that Australia's political and security relations with China were partly influenced by "functional distance;" As Australia tends to find political and security relations with Indonesia very difficult, Japan does so with China, and vice versa. The diplomat did not conceal the influence of China's trade factor on Australia's softer stance: "Australia has found itself in a difficult situation in terms of its commitment to improving China's human rights records or promoting democracy, given China's growing significance in Australia's trade.",10

In response, Rice and Japanese Foreign Minister Taro Aso came all the way to Sydney in March 2006 to "air their shared concerns about Australia's growing accommodation with China," an issue that was "indeed uppermost in their minds."11 Nevertheless, their joint statement merely mentioned that three foreign ministers "welcomed China's constructive engagement in the region and concurred on the value of enhanced cooperation with other parties such as ASEAN and the Republic of Korea," a stance that reflected well Australia's anxiety that the TSD that "has made Beijing deeply uneasy" would not been seen as a way of containing China. ${ }^{12}$ Australia continued to take a different policy stance toward China and developed relations almost autonomously. For instance, in April 2006, while the United States still harboured concerns that uranium exported to China might be used for military purposes, an agreement was reached between Wen Jiabao and Australian Prime Minister Howard for the export of 20,000 tons of uranium from Australia to China over ten years. The announcement of the establishment of an Australia-

\footnotetext{
${ }^{8}$ Ibid., 108.

9 David Walton, "Australia and Japan," in Trading on Alliance Security: Australia in World Affairs, 2001-2005, ed. James Cotton and John Ravenhill (Oxford University Press, 2007).

10 Personal interview, Canberra, August 2, 2006.

11 White, 109.

12 Greg Sheridan, The Partnership: The Inside Story of the U.S.-Australian Alliance under Bush and Howard (Sydney: University of New South Wales Press, 2006), 201.
} 
China strategic dialogue on 6 September 2007 can be seen as a diplomatic balancing act by Howard to substantially enhance relations with China while maintaining close security ties with the United States and Japan. ${ }^{13}$

Accordingly, Japan's support for Australia's inclusion in East Asian community-building, which aimed to enhance the role of its partnership with Australia as a valued partner and counter China's ambition to dominate the region, were not realised. For instance, during the first EAS held in December 2005 in Kuala Lumpur, China insisted that ASEAN+3, rather than the EAS, be used as a forum for discussing East Asian community-building. China's approach contrasted clearly with that of Japan, which advocated a wider membership including three democratic nations (i.e., Australia, India and New Zealand) to reduce China's influence. However, Japanese policy specialists such as Noboru Hatakeyama, who played a pivotal role in promoting Japan's FTA policy, attribute the difficulty in forming a regional community in East Asia to the fact that some regional countries like China do not share values toward freedom, democracy, or human rights with Japan. ${ }^{14}$ Japan's claim on a wider membership prevailed for the inaugural EAS partly due to India's strong claim on the use of the EAS as a vehicle for East Asian community-building. This view was also supported by Indonesia, which worried about the negative consequence of China's growing regional power on ASEAN's influence, and favoured involving countries like India and Australia to provide balance. ${ }^{15}$ Nevertheless, Australia, rather than Indonesia and India, was quoted by a senior official of Japan's MOFA as not exercising a strong influence on this battle, ${ }^{16}$ although a senior Australian diplomat's rebuttal claimed that Howard, who was eventually impressed by the EAS's function, could not take a leading role in agenda-setting as Australia was a newcomer. ${ }^{17}$ In short, the TSD process has not so far fulfilled the function the United States initially intended since it has failed to press Australia to take a similar policy stance on China.

\footnotetext{
13 David Walton, "Australia and Japan: Towards a New Security Partnership?" Japanese Studies 28, no. 1 (2008): 81.

${ }^{14}$ Noboru Hatakeyama, "East Asian Community: Prospects and Problems towards a Regional FTA," Nihon Keizai Shimbun, November 25, 2005.

15 Takashi Terada, "The Origins of ASEAN+6: Japan's Initiatives and the Agent-Structure Framework," The Pacific Review (2009).

16 Personal interview, Tokyo, December 24, 2005.

${ }^{17}$ Personal interview, Canberra, August 2, 2006.
} 


\section{Australia's Vulnerability: Quadrilateral Approach}

A quadrilateral approach to China was formulated by Japanese Prime Minister Shinzo Abe and Australia was viewed as an essential part as Abe considered Australia a nation that shared common values with the Unites States and Japan. However, a concealed objective behind the development was to encircle China, and Australia refused participation to not harm relations with China, illustrating another example of Australia's vulnerability toward China.

As the second Armitage-Nye report highlights, the most fundamental element that politically connects the United States, Japan, and Australia for security cooperation is shared values such as democracy, human rights, and religious freedom. ${ }^{18}$ The significance of those values was stressed by President Bush and Prime Minister Abe despite their failure to forge a strong personal rapport, which had flourished between Bush and Japanese Prime Minister Koizumi. For instance, in September 2007, Bush proposed the formation of a new Asia Pacific Democracy Partnership to "provide a venue in which free nations will work together to support democratic values, strengthen democratic institutions, and assist those who are working to build and sustain free societies across the Asia Pacific region.," his first administrative policy speech at the Diet in January 2007, Prime Minister Abe who hoped to conduct "assertive diplomacy" urged the need to strengthen partnerships with nations that shared those values, referring to Australia and India as such nations. ${ }^{20}$ This value-oriented foreign policy approach promoted by Abe found India as an additional regional power with which three nations could work together to develop a regional mechanism to engage China peacefully. The same purpose was embedded in the "Arc of Freedom and Prosperity" concept promoted by his foreign minister, Aso.

While Abe ceased prime ministerial visits to the Yasukuni Shrine, to which Koizumi had made an annual event that damaged relations with China and Korea, with a view toward repairing those relations, his highly ideologically-coloured foreign policy approach, as seen in the promotion of ties with nations that share "common values" with Japan, had already been concretely expressed in his book. Abe insisted on organizing a summit meeting among Japan, Australia, the United States, and India, all of which, he believed, share universal values such as democracy and respect for human rights. The purpose behind this assertion was to

\footnotetext{
18 Armitage and Nye, 19.

19 White House Office of the Press Secretary, "U.S. Commitment to Strengthen Forces of Freedom, Prosperity in Region," September 7, 2007.

$20 \mathrm{http} / / /$ www.kantei.go.jp/jp/abespeech/2007/01/26sisei.html
} 
discuss ways to make East Asian countries, including China, accept those values. ${ }^{21}$ For instance, in his speech at the Indian Parliament on 22 August 2007, Abe introduced a new regional concept, a "broader Asia," by stating that "the Pacific and the Indian Oceans are now bringing about a dynamic coupling as seas of freedom and of prosperity. A 'broader Asia' that broke away geographical boundaries is now beginning to take on a distinct form." 22 Abe's message to India was to further promote regional cooperation within this regional framework by "incorporating the United States of America and Australia." The purpose behind this proposal was mentioned later in a speech: "I feel that it is imperative that the democratic nations located at opposite edges of these seas deepen the friendship among their citizens at every possible level., ${ }^{, 3}$ One reason Abe needed to introduce the concept of "broader Asia," despite Australia and India becoming official EAS members and being acknowledged as East Asian nations, was to enable engagement by the United States, which was an EAS member but which Abe considered essential to this regional concept. In this sense, Abe was more explicit in expressing its desire to promote an exclusive group of democratic countries centred on the United States than Koizumi, and he was seen as "the most vocal supporter" of the quadrilateral forum. ${ }^{24}$ A senior Department of Foreign Affairs and Trade official declared that Abe came to view Australia as a significant strategic partner after Australia decided to increase help for Japan's Self Defense Forces (JSDF) in Iraq and to promote Japan's effort to conclude the Australia-Japan FTA feasibility study. ${ }^{25}$ Japan's ASEAN+6 approach, embodied as the establishment of the EAS in 2005 and the Economic Research Institute for ASEAN and East Asia (ERIA) in 2007, which include Australia and India, was developed as part of Abe's foreign policy agenda, and the issue of how to respond to the rise of China was a common influence on both political and economic regionalism schemes.

Abe's support for the quadrilateral approach sustained by his emphasis on values such as democracy and human rights came to be strengthened after he met with the U.S. Vice-President Dick Cheney in February 2007. They discussed the idea of India's possible participation with Japan, Australia, and the United States, to form a quadrilateral grouping of like-minded democratic nations. ${ }^{26}$ This proposal led to an experimental attempt to form the grouping through an informal meet-

\footnotetext{
21 Shinzo Abe, Utukushii Kuni-he [Towards a Beautiful Country] (Bungei Shunjyusha, 2006).

22 Shinzo Abe, "Confluence of the Two Seas," (speech, Parliament of the Republic of India, August 22, 2007.

23 Ibid.

24 Chanlett-Avery and Vaughn,14.

25 Personal interview, Canberra, August 2, 2006.

26 Ministry of Foreign Affairs of Japan, "Visit to Japan of the Honorable Dick Cheney, Vice President of the United States of America (Summary)," February 22, 2007, http://www.mofa. go.jp/region/n-america/us/vpv0702.html
} 
ing in May 2007, participated by representatives from the four nations as a sideline meeting of the ASEAN Regional Forum (ARF). China was wary of such a move and issued "formal diplomatic protests to Australia, Japan, and India out of concern that they were forming a security alliance with the United States against China." ${ }^{27}$ India's participation in the framework can be rationalized by its complex relations with China as seen in territorial disputes over Kashmir, Sikkim, and Anurachal Pradesh, which India might have wanted to discuss as a way of putting a pressure on China.

However, Australia was not keen to use shared values as a political tool to form an exclusive framework, as it was seen as an annoyance to China. For instance, in their meeting in Washington in July 2005, Howard was reported to have turned down President Bush's request that the United States and Australia work together to "reinforce the need for China to accept certain values as 'universal." Howard's approach towards China was "to build on the things that we have in common, and not become obsessed with the things that make us different." 28

Australia's reserved stance on China was shared more by Japan after Prime Minister Abe resigned in September 2007 and Yasuo Fukuda, who placed a greater emphasis on relations with China, replaced him. Fukuda naturally displayed little enthusiasm for continuing with the four-nation strategic dialogue, and Stephen Smith, Australian Foreign Minister during the Rudd administration, also indicated that the dialogue had concerned China and that Australia had no intention of supporting a framework of this type. ${ }^{29}$ One reason for Rudd's decision to refuse to allow Australia's uranium sales to India while supporting the International Atomic Energy Association's approval of a uranium deal between India and the United States was not to provoke China, which tended to worry about the containment movement. The preconditions for the ASEAN +6 framework implemented to counter the perceived negative aspects of China's rise have transformed with the change of administrations in the region. The political implications of this change (e.g., differences in values held by different nations) have eroded the will to promote the quadrilateral framework as a way of checking China's growing regional influence. At the same time, they have eliminated the strategic value from partnerships among Japan, India, and Australia.

27 Chanlett-Avery and Vaughn, 3.

28 Straits Times, August 19, 2005.

${ }^{29}$ Nihon Keizai Shimbun, February 16, 2008. 


\section{Rise of Military China: Inevitable Balancing}

The distance between Australia and China has allowed Australia to not be anxious about China's military power. This so-called functional distance helped Australia's relations with China develop comfortably, unlike Japan, which has struggled with China over maritime territories and historical interpretations originating from geographical proximity. An Australian senior official in charge of China relations has stated, "Australia has found itself in a difficult situation in terms of its commitment to improving China's human rights records or promoting democracy, given China's growing significance in Australia's trade." However, closer relations with the United States, which has more concern over China's military rise, has inevitably transformed Australia's traditional stance on China. China's double-digit rises in declared defence spending the past two decades, and undeclared spending reported to be much higher, is a major concern shared by almost all Asia Pacific counties. If transparency were not secured, momentum for trilateral/quadrilateral defence cooperation between Australia, Japan, India, and the United States would be more firmly established. For the United States, Japan, and Australia, their major trading partner (and foreign creditor to the United States) is also their major source of threat. Frequent consultations through more institutionalised frameworks among the three nations are needed to identify their common approaches toward persuading China to engage regional stability.

Importantly, Australia under the Rudd administration intended to take more independent response to the military rise of China, as was articulated in a 2009 defence white paper that saw China as potentially "the strongest Asian military power" and warned that "the pace, scope and structure of China's military modernization have the potential to give its neighbors cause for concern if not carefully explained." The defence white paper articulated Australia's plan to hedge against a situation in which China challenged U.S. hegemony in the region by planning a military build-up over two decades. Rudd called this build-up "the most powerful, integrated and sophisticated set of military capabilities" Australia has had, which would include the acquisition of three air warfare destroyers, eight new frigates, and 12 new submarines by 2030. Given the statement by Admiral Wu Shengli, head of China's navy, in April 2009 that the navy would "move faster in researching and building new-generation weapons to boost the ability to fight regional sea wars," Australia's declaration to see China as a major threat to its security represents its potential engagement in U.S. battles against China, or at least its continued military sophistication. In this case, Japan's promise to accelerate an array of defence cooperation initiatives with Australia, as declared by both countries' defence ministers in December 2008, and Japan's choice of India as the 
third nation, after the United States and Australia, to launch a joint security declaration in November 2008, appeared to lay a foundation for potential U.S. engagement in a more formal multilateral defence and security arrangement if China's maritime ambitions continued. Given President Obama's Asia pivot strategy, in which Australia serves as a key player for U.S. military deployment, a 2013 defence white paper, the first to be launched under Prime Minister Gillard, stresses Australia's need to sustain American military presence and its Asia pivot strategy, while it displays Australia's changing views on China's rise which Australia "welcomes". The new assessment is based on a more optimistic future scenario, described as the United States and China being "able to maintain a constructive relationship".

As a method of Australia's preventive diplomacy, Kevin Rudd, when prime minister in 2008, called for an Asia Pacific Community (APC). A major rationale behind his proposal was the belief that there was no Asian regional institution that had "the ability to deal comprehensively with all of the economic, political and security issues" since none entailed together all of what he called essential participants, such as the United States, China, Japan, India, Russia, and Indonesia. The EAS, through the participation of the U.S. and Russian presidents in 2011, in addition to 16 other leaders, can be viewed as the most useful framework for dealing with regional security issues. This can be seen in the way Rudd delineated in the APC idea and in the fact that one of the key agendas in the subsequent EAS held in Jakarta in November 2011 was the territorial disputes in the South China Sea, as President Obama already declared during his visit to Indonesia in November 2010. The United States and other democratic nations in the region, such as Australia, have begun to construct a rules-based framework that tackles traditional "hard" security issues, such as territorial disputes in the South China Sea with a hope that China would abide by it.

This has been marked by a shift away from a focus on the ARF, which has the reputation of being more a discussion session than a meeting with clear political goals, and toward emphasis on more substantive deliberations at the EAS, in which the United States is now a full participant. According to White, who asserts that power sharing between the United States and China is the best option for stopping the escalation of bilateral tension toward a disastrous military confrontation, this shift was accompanied by Obama's announcement in November 2011 that 2,500 U.S. Marines would be stationed at the Australian Army's Robertson Barracks in Darwin, representing an American attempt to push back China's challenge to American primacy and Australia's readiness to be engaged in the orderbuilding in the region, 


\section{Strong Shared Concern: Military Rise of China}

America's concern over China's increasing military build-up was well reflected in the 2006 Quadrennial Defense Review (QDR), which declares China as "the greatest potential to compete militarily with the United States and field disruptive military technologies that could over time offset traditional U.S. military advantages absent U.S. counter strategies. " ${ }^{30}$ Importantly, such a stark view of China's increasing military spending as threatening the delicate security balance in East Asia has gradually percolated through Japan, as insinuated in defence white papers. Howard shared this concern over China's growing military spending: "The pace and scope of its military modernization, particularly the development of new and disruptive capabilities such as the anti-satellite missile, could create misunderstandings and instability in the region,"31 although Downer continued to be sanguine about China by seeing China's military budget as reasonable and benign. ${ }^{32}$

The military, rather than economic, rise of China is a shared concern among major states in the Asia Pacific including Australia. Although trilateral and quadrilateral ministerial processes have faced setbacks, to a different degree, defence cooperation, including military exercises, has progressed. In June 2007, JSDF joined the U.S.-Australia joint the military exercise Talisman Saber for the first time as an observer. As this is designed to train both military forces to improve their "combat readiness and interoperability, ${ }^{, 33}$ JSDF's participation was expected to potentially help improve Japanese defence and intelligence capabilities within a broader trilateral framework. Equipment compatibility was essential in joint military operation, and Australia's decision to acquire "three destroyers equipped with the Aegis combat system, the same system used by American and Japanese militaries," 34 was an initial step for its participation in trilateral defence cooperation. In October 2007, navies from the three countries conducted a drill near Kyushu, the first trilateral $\mathrm{P}-3 \mathrm{C}$ exercise, to simulate "search and rescue activities as well as an attack on a Japanese escort ship." ${ }^{35}$ Singapore also joined these four nations in naval exercises in the Bay of Bengal in September 2007 with over 20,000 personnel, 28 ships, 150

\footnotetext{
30 United States Department of Defense, Quadrennial Defense Review Report, February 2006, 19.

31 Reuters News, July 5, 2007.

32 Mark Thompson, "The Japan-Australia Strategic Relationship: An Australian Perspective," (paper submitted to the $4^{\text {th }}$ Australia and Japan 1.5 Track Security Dialogue, Canberra, December 10-11, 2007): 31 .

33 http://www.defence.gov.au/exercises/ts07/default.htm

34 Dow Jones International News, June 5, 2007.

35 Chanlett-Avery and Vaughn, 12.
} 
aircraft, and three aircraft carriers. ${ }^{36}$ Bristled by these exercises, China questioned whether this exercise may lead to an "Asian NATO," despite U.S. insistence that "the exercises were not directed at any particular country." Nevertheless, the U.S. Navy declared that the demonstration "provides a message to other militaries, and our own, that we are capable of operating together and that we work together with our regional partners to ensure stability in the region. ${ }^{, 37}$

Rudd took a similar view on the military rise of China, as was articulated in a 2009 defence white paper that saw China as potentially "the strongest Asian military power" and warned that "the pace, scope and structure of China's military modernization have the potential to give its neighbors cause for concern if not carefully explained." 38 The 2009 defence white paper articulated how Australia could hedge against a situation in which a militarily strong China backed by rapid economic growth might challenge U.S. hegemony in the area by planning a military build-up over two decades, which Rudd called "the most powerful, integrated and sophisticated set of military capabilities Australia has had." ${ }^{39}$ This build-up would include the acquisition of three air warfare destroyers, eight new frigates, and 12 new submarines by 2030. Given a statement by Admiral Wu Shengli, head of China's navy, in April 2009 that the navy would "move faster in researching and building new-generation weapons to boost the ability to fight regional sea wars, ${ }^{, 40}$ Australia's declaration of China as a major threat to its security represents its potential engagement in U.S. battles against China, or at least its continued military sophistication. In this case, Japan's promise to accelerate an array of defence cooperation with Australia, as declared by the two countries' defence ministers in December 2008, and Japan's choice of India as the third nation, after the United States and Australia, to launch a joint security declaration in November 2008, appeared to lay a foundation for potential U.S. engagement in a more formal multilateral defence and security arrangement if China's maritime ambitions continued.

Yet, as touched upon earlier, the 2013 defence white paper "does not approach China as an adversary", reflecting Gillard's more nuanced stance on China which included her keener interest in expanding economic relations China, as seen in the agreement for the convertibility of the Australian and Chinese currencies in March 2013. It nonetheless refers to the future scenario that hostile powers might employ coercion or intimidation in the Indo-Pacific zone and that miscalculation could escalate tensions in the South China Sea. So, the 2013 paper is another product of

36 United States Department of the Navy, "Kitty Hawk, Allies Complete Malabar Exercise," U.S. Navy Press Release, September 10, 2007.

${ }^{37}$ Ibid.

38 Australian Government Department of Defence, Defending Australia in the Asia Pacific Century: Force 2030 (Canberra, 2009): 34.

39 The Economist, May 9, 2009.

40 The Australian, May 6, 2009. 
Australia's struggle to balance between the maintenance of the alliance with the United States and the efforts not insult China.

\section{Conclusion}

Australia's dual identity as a major natural resource and agricultural exporter and American loyal ally inevitably forces it to employ an economically friendly and militarily harsh stance against China. This means Australia has found it occasionally difficult to act as a keen player in efforts to encircle China, as seen in its apathetic approach to the TSD and quadrilateral forums. Thus, "how defense cooperation can be strengthened without alienating China" ${ }^{" 41}$ is seen as a major task Australia needs to overcome. This stance is strongly encouraged by the fact that the energy boom arising from China's skyrocketing demand for iron ore and coal risks faster inflation and requires higher interest rates, and the Australian dollar has been soaring. However, this cycle has made it difficult for non-energy sectors to export. Education, which brought 17 billion dollars to Australia in 2010, has suffered since studying in Australia is more expensive. Ranked after coal and iron ore as the most lucrative source of foreign currency earnings, the educational industry has developed mainly through attracting students from Asia, accounting for more than 70 percent of all students in Australia. More highly evaluated Australian dollars would make it more difficult for these students to pay tuition fees and cover living costs, and the total number of Asian students would be expected to decrease. As a result, subsidies paid for local students would be also reduced, possibly damaging the availability of a skilled and talented workforce. The Asian Century white paper, designed to seek a way of maximising opportunities to be presented by growing Asian markets, includes the agenda of "revamping trade policy," which would be linked up with the diversification of Australia's trade. The crux of the argument in terms of Australia's future China policy is whether Australia's decision to reduce the trade reliance on China will urge Australia's concern over the military rise of China to develop, as was seen in its support for U.S. marine deployment in Darwin.

${ }^{41}$ Alan Dupont, "Unsheathing the Samurai Sword: Japan's Changing Security Policy," Lowy Institute Paper No. 3 (2004): 49. 


\section{Bibliography}

Abe, Shinzo. Utukushii Kuni-he [Towards a Beautiful Country]. Bungei Shunjyusha, 2006.

- "Confluence of the Two Seas." Speech, Parliament of the Republic of India, August 22, 2007.

Australian Government. Budget Paper No. 1, May 10, 2011.

Australian Government Department of Defence. Defending Australia in the Asia Pacific Century: Force 2030. Canberra, 2009.

_. Defence White Paper 2013. Canberra, 2013.

Dupont, Alan, "Unsheathing the Samurai Sword: Japan's Changing Security Policy.” Lowy Institute Paper No. 3 (2004).

Hanson, Fergus. "2008 Lowy Poll: Australians Wary over China's Rise." Lowy Institute for International Policy, September 30, 2008.

Gillard, Julia. Speech to the AsiaLink and Asia Society Lunch, Melbourne, Australia, September 28, 2011.

Hatakeyama, Noboru. "East Asian Community: Prospects and Problems towards a Regional FTA.” Nihon Keizai Shimbun, November 25, 2005.

Sheridan, Greg. The Partnership: The Inside Story of the U.S.-Australian Alliance under Bush and Howard. Sydney: University of New South Wales Press, 2006.

Terada, Takashi. "The Origins of ASEAN+6: Japan's Initiatives and the AgentStructure Framework." The Pacific Review (2009).

Thompson, Mark. "The Japan-Australia Strategic Relationship: An Australian Perspective." Paper submitted to the $4^{\text {th }}$ Australia and Japan 1.5 Track Security Dialogue, Canberra, December 10-11, 2007.

United States Department of Defense. Quadrennial Defense Review Report. February 2006.

United States Department of the Navy. "Kitty Hawk, Allies Complete Malabar Exercise." U.S. Navy Press Release, September 10, 2007.

Walton, David. "Australia and Japan." In Trading on Alliance Security: Australia in World Affairs, 2001-2005, edited by James Cotton and John Ravenhill. Oxford University Press, 2007.

—. "Australia and Japan: Towards a New Security Partnership?" Japanese Studies 28, no. 1 (2008).

White, Hugh. "Trilateralism and Australia: Australia and the Trilateral Security Dialogue with America and Japan." In Asia Pacific Security: U.S., Australia and Japan and the New Security Triangle, edited by William T. Tow et al. Routledge, 2007). 


\section{About the Author}

Takashi TERADA is Professor of International Relations at Doshisha University in Kyoto. He received his Ph.D. from Australian National University in 1999. Before taking up his current position in April 2012, he was an assistant professor at National University of Singapore (1999-2006) and associate and full professor at Waseda University (2006-2011). He also has served as a visiting professor at University of Warwick, U.K. (2011 and 2012) and a Japan Scholar at Woodrow Wilson International Center for Scholars, Washington D.C. (2012). His areas of specialty include international political economy in Asia and the Pacific, theoretical and empirical studies of Asian regionalism and domestic and international politics regarding FTAs, and his articles were published by major international academic journals including The Pacific Review, Journal of Politics, Australian Journal of International Affairs, Asia Pacific Economic Papers. His most recent publications include East Asia and the Asia-Pacific; Competing Regional Integration Initiatives (2013 University Tokyo Press). He is the recipient of the 2005 J.G. Crawford Award.

Address: Department of Political Science, Faculty of Law, Doshisha University, Karasuma-Higashi-iru, Imadegawa-dori, Kamigyo-ku, Kyoto 602-8580, Japan.

Email:.jpsttt@hotmail.com 